\title{
Integration of Quality Management System in the Malaysian Construction Industry
}

\author{
Poh Ngoh Kiew ${ }^{1}$, Syuhaida Ismail ${ }^{2}$ and Aminah Mohd Yusof ${ }^{3}$ \\ 1,2 UTM RAZAK School of Engineering \& Advanced Technology, Universiti Teknologi Malaysia Kuala \\ Lumpur, Jalan Semarak, Kuala Lumpur \\ ${ }^{3}$ Faculty of Civil Engineering, Universiti Teknologi Malaysia
}

Correspondence should be addressed to: Poh Ngoh Kiew; ngohkiew@gmail.com

Received date: 28 December 2015; Accepted date: 7 January 2016; published date: 28 December 2016

Academic Editor: Heap-Yih Chong

Copyright ( 2016. Poh Ngoh Kiew, Syuhaida Ismail and Aminah Mohd Yusuf. Distributed under Creative Commons CC-BY 4.0

\begin{abstract}
Quality management system (QMS) is defined as the managing structure, responsibilities, procedures, processes, and management resources to implement the principles and action lines needed to achieve the quality objectives of an organization. QMS is conventionally being associated with the manufacturing industry as it is used to direct and control an organization with regard to the end-product quality via various QMS manufacturing models, namely Malcolm Baldrige National Quality Award, the ISO 9000 quality standards, Total Quality Management (TQM), Six Sigma and Lean. However, since the construction industry appears to be going through a period of introspection, with the increasing of technological innovation in design concepts, use of new and unique materials, novel methods of construction, complex social issues, rapid environmental change as well as obnoxious problems of delay, over-budget and low quality, QMS is observed by this paper as the solution to this dilemma. Hence, this paper aims at appraising the integration of QMS in the Malaysian construction industry. It is expected that the findings of this paper would help the project management team of the construction projects to efficiently manage the construction activities throughout the whole project life cycle from pre-contract to post-contract phase via the integration of QMS.
\end{abstract}

Keywords: Quality management system, Construction Industry, Critical Success Factors, Project Life Cycle.

Cite this Article as: Poh Ngoh Kiew, Syuhaida Ismail and Aminah Mohd Yusuf (2016)," Integration of Quality Management System in the Malaysian Construction Industry ", The Journal of Organizational Management Studies, Vol. 2016 (2016), Article ID 117211, DOI: 10.5171/2016.117211 


\section{Introduction}

With the turn of this new millennium, the construction industry appears going through a period of introspection, with the increasing of technological innovation in design concepts, use of new and unique materials as well as novel methods of construction, complex social issues and rapid environmental change. These changes affect the way business is conducted; where quality expectation of clients and end-users has grown relentlessly due to an increasing demand for better living standard and value for money (Al-Momani, 2000; Economic Planning Unit, 2010). According to Nelson and Holt (1999), no organization operating in the construction industry, whether large or small, private or public, can afford to ignore its changing environment if it is to survive.

In Malaysia, residential development in low, medium and high cost demonstrates very strong demands, needs and supply due to population increase, which is expected to be about 32 millions in year 2020 (Economic Planning Unit, 2010). Hence, it is a major challenge in the areas of efficiency and effectiveness of the Quality Management System (QMS) in the construction industry in order to sustain in this complex environment. Therefore, management of construction companies is required to have sufficient understanding and ability in addressing complexity in planning, coordination, and control requirements (Austin et al, 2002; Jack and Samuel, 2006) in order to work well, work fast, work smart, and produce results for the projects. However, a lot of projects performance dissatisfaction can be found among both private and public projects. To deal with project performance efficiently and effectively for the balance on the better value for clients and reasonable profits for the construction companies to ensure their longterm future, integrating of quality management system (QMS) is essential to ensure sustainability in the construction industry. Therefore, this paper aims at appraising the integration of QMS in the
Malaysian construction industry. The general review on the QMS is undertaken, followed with the in-depth discussion on the ISO 9000-Based Quality Management Systems, which is the main mechanism of the QMS integration in the Malaysian construction industry.

\section{Reviews of Quality Management System (QMS)}

There are many definitions of the Quality Management System (QMS). QMS can be defined as "the managing structure, responsibilities, procedures, processes and management resources to implement the principles and action lines needed to achieve the quality objectives of an organisation". In addition, QMS is also defined by The International Organization for Standardization (ISO) as "the management system used to direct and control an organization with regard to quality". The models such as Malcolm Baldrige National Quality Award, the ISO 9000 quality standards, Total Quality Management (TQM), Six Sigma and Lean are amongst the acknowledged QMS models worldwide and being used successfully across different industries, particularly the manufacturing industry.

Nevertheless, it is important to note that successful implementation of QMS in manufacturing are being adopted and integrated into construction industry for more than two decades, especially the ISO 9000 series of Quality Systems Standards. The concept of QMS as an initiative is to solve quality problems and to meet the needs of end-users (Kanji and Wong, 1998). There are many reasons and benefits that have been suggested as to why companies seek quality certification (Yeoh et al., 1996). The effects of QMS implementation have also been studied by McIntyre and Kirschenman (2000), where it is found that more repeat customers and reduced rework are amongst the most obvious benefits demonstrated via the implementation of QMS. Effects of customer satisfaction are being concluded by 
Torbica and Stroh (1999) as "For the first time an empirical study has confirmed that implementation of TQM is positively associated with home-buyer satisfaction". Love et al. (1999) who concluded a study on the effects of rework in construction project also claim that the increased cost and time are found to be as high as 12 percents and 11 percents respectively.

On the other hand, the survey conducted by Shaw (1995) on 35 selected contractors in investigating the original motivations in seeking a QMS certification also shows the positive effects of QMS implementation. The summary of the survey results is indicated in Table 1. From the results, five out of seven items, which are from item 3 to 7 , provide the least motivations to the organizations. It is found by Shaw (1995) that the constructors failed to gain benefits due to wrong thinking on implementing the QMS, which is due to mainly the pressure of the government or clients in seeking qualified certification and the solution for the problems in cost, quality, risk and the like. Therefore, the overall benefits gained as a result of implementing the QMS have not been significant.

Table 1: Original motivations survey results on seeking a QMS

\begin{tabular}{|c|l|c|}
\hline Item & \multicolumn{1}{|c|}{ Motivations } & $\begin{array}{c}\text { Agreed } \\
\text { Percentage (\%) }\end{array}$ \\
\hline 1 & $\begin{array}{l}\text { To improve the company's quality image in the } \\
\text { construction industry. }\end{array}$ & $57 \%$ \\
\hline 2 & To improve the company's efficiency and management. & $57 \%$ \\
\hline 3 & $\begin{array}{l}\text { To resolve the problems with poor quality arising } \\
\text { construction processes. }\end{array}$ & $9 \%$ \\
\hline 4 & To reduce the failure costs and liability risks. & $9 \%$ \\
\hline 5 & To fulfill the mandate from the Government & $94 \%$ \\
\hline 6 & To satisfy the demands from the private owners/ clients & $6 \%$ \\
\hline 7 & $\begin{array}{l}\text { To be a stepping stone for implementing Total Quality } \\
\text { Management (TQM) }\end{array}$ & \\
\hline
\end{tabular}

In general, there is a lack of appreciation of QMS approach in managing construction projects due to non-standardisation, where projects look similar but not identical with non-repetition. In support of this, many authors point out that non-standardisation is one of the main barriers of implementation of quality tools in construction (Nesan and Holt, 1999; Karim et al., 2005; Peter et al., 2010).

Moreover, Lahndt (1999) concludes that although the construction industry needs the same types of tools and for the same reasons, but due to dissimilarity of industries, the construction industry player cannot apply them as they are. In actual fact, the construction industry has been criticised for its poor performance and productivity in relation to other industries (Kanji and Wong, 1998; Nesan and Holt, 1999; Durdyev et al., 2011). Moreover, construction works are heavily relied on professional judgment and construction processes, which are complex in quality definition. There are many parties involved in the construction process with the internal and external influences; where involvement from authorities to general workers in different phases and each one plays a different role in delivering a quality project. Failure of any of the parties of each phase in the process will affect the quality of the final project (Kanji and Wong, 1998). Therefore, further rethinking on the 
implemented management tools in construction industry is needed among contractors and researchers to ensure better performance of construction industry as a whole.

\section{ISO 9000-Based Quality Management Systems}

The ISO was founded in 1946 in Geneva, Switzerland (Praxiom, 2013). The ISO 9000 series of Quality Systems Standards was first published by The ISO in 1987 based on the BS 5750 series of standards from British Standards Institution (BSI) that were proposed to ISO in 1979. Since then, it has been wisely implemented worldwide to an atmosphere of continual improvement and customer satisfaction. It deals with the fundamentals of Quality Management Systems (Tsim et al., 2002), which provides comprehensive guidance on the scope, implementation and the principles based on eight principles of Total Quality Management (TQM) (Beattie, 1999; Jay and Barry, 2014) from Dr. Deming's Fourteen Points. These include customer focus, leadership, involvement of people, process approach, system approach to management, continual improvement, factual approach to decision making and mutually beneficial supplier relationship as shown in Table 2 (David et al., 2013).

Table 2: Eight Principles of the ISO 9000's Basis

\begin{tabular}{|c|c|c|}
\hline Item & Principles & Description \\
\hline 1 & Customer Focus & $\begin{array}{l}\text { Understand the customer's needs, meet the customer's } \\
\text { requirements, and strive to exceed to the customer's expectation }\end{array}$ \\
\hline 2 & Leadership & $\begin{array}{l}\text { Establish unity of purpose and organizational direction and provide } \\
\text { an environment that promotes employee involvement and } \\
\text { achievement of objectives. }\end{array}$ \\
\hline 3 & Involvement of people & $\begin{array}{l}\text { Take advantages of fully involved employees, using all their abilities } \\
\text { for the benefit of the organization. }\end{array}$ \\
\hline 4 & Process Approach & $\begin{array}{l}\text { Recognize that things accomplished are the results of processes } \\
\text { along with related activities and resources that must be managed. }\end{array}$ \\
\hline 5 & $\begin{array}{l}\text { System Approach to } \\
\text { Management }\end{array}$ & $\begin{array}{l}\text { The multiple interrelated processes that contribute to the } \\
\text { organization's effectiveness are a system and should be managed as } \\
\text { a system. }\end{array}$ \\
\hline 6 & Continual Improvement & $\begin{array}{l}\text { Continual improvement should be a permanent objective applied to } \\
\text { the organization and to its people, processes, systems, ands } \\
\text { products. }\end{array}$ \\
\hline 7 & $\begin{array}{l}\text { Factual Approach to } \\
\text { Decision Making }\end{array}$ & $\begin{array}{l}\text { Decisions must be based on the analysis of accurate, relevant, and } \\
\text { reliable data and information. }\end{array}$ \\
\hline 8 & $\begin{array}{l}\text { Mutually Beneficial } \\
\text { Supplier Relationship }\end{array}$ & $\begin{array}{l}\text { Both the organization and the supplier benefiting from one } \\
\text { another's resources and knowledge results in value for all }\end{array}$ \\
\hline
\end{tabular}

Poh Ngoh Kiew, Syuhaida Ismail and Aminah Mohd Yusuf (2016), The Journal of Organizational Management Studies, DOI: $10.5171 / 2016.117211$ 
The ISO9000 series of standards have been widely implemented worldwide to an atmosphere of continual process improvement and customer satisfaction. There are many versions of the ISO series as shown in Table 3. For instance, the version 1987 emphasizes the conformance with procedures rather than the overall process of management; whereas the version 1994 emphasizes the quality assurance via preventive actions and continues to require evidence of compliance with the documented procedures. However, the version 2000 emphasizes the effectiveness via process performance metrics where require design and development procedures for new products creation with the involvement of top executives. The version 2008 only introduces clarifications to the existing requirements of ISO 9001:2000. Hence, the IS09001:2008 establishes the requirements of a quality management system; ISO 9000:2005 covers the basic concepts and language; ISO 9004:2009 is designed to focus on how to make a quality management system more efficient and effective and ISO 19011:2011 sets out guidance on internal and external audits of quality management systems. 
Table 3: Evolution of ISO 9000 Standards

\begin{tabular}{|c|c|c|c|c|c|}
\hline Version & Description & ISO 9001 & ISO 9002 & ISO 9003 & ISO 9004 \\
\hline$\stackrel{5}{\approx}$ & $\begin{array}{l}\text { Influenced by existing U.S. } \\
\text { and other Defense } \\
\text { Standards ("MIL SPECS"). } \\
\text { Emphasized conformance } \\
\text { with procedures rather than } \\
\text { the overall process of } \\
\text { management. }\end{array}$ & $\begin{array}{l}\text { Quality } \\
\text { assurance in } \\
\text { design and } \\
\text { development }\end{array}$ & $\begin{array}{l}\text { Quality } \\
\text { assurance in } \\
\text { production } \\
\text { and } \\
\text { installation } \\
\text { (No new } \\
\text { design) }\end{array}$ & $\begin{array}{l}\text { Quality } \\
\text { assurance } \\
\text { in final } \\
\text { inspection } \\
\text { and test }\end{array}$ & \\
\hline ڤ̆ & $\begin{array}{l}\text { Emphasized quality } \\
\text { assurance via preventive } \\
\text { actions, instead of just } \\
\text { checking final product, and } \\
\text { continued to require } \\
\text { evidence of compliance } \\
\text { with documented } \\
\text { procedures. } \\
\end{array}$ & & & & \\
\hline ఫั & $\begin{array}{l}\text { Replaced all three former } \\
\text { standards of } 1994 \text { issue, } \\
\text { ISO 9001, ISO } 9002 \text { and } \\
\text { ISO 9003. }\end{array}$ & $\begin{array}{l}\text { "Process managen } \\
\text { and optimization o } \\
\text { activities, instead } \\
\text { final product. In Is } \\
\text { structure was aban } \\
\text { the } 5 \text { sections. } \\
\end{array}$ & $\begin{array}{l}\text { ent" was the m } \\
\text { a company's } \\
\text { f just inspectic } \\
\text { O } 9001,20 \text {-cla } \\
\text { loned and repl }\end{array}$ & $\begin{array}{l}\text { nitoring } \\
\text { sks and } \\
\text { of the } \\
\text { se } \\
\text { ced with }\end{array}$ & \\
\hline$\stackrel{\overbrace{}}{\stackrel{1}{1}}$ & $\begin{array}{l}\text { Covers the basic concepts } \\
\text { and language. }\end{array}$ & $\begin{array}{l}\text { Quality } \\
\text { management } \\
\text { systems. } \\
\text { Fundamentals } \\
\text { and vocabulary. }\end{array}$ & & & \\
\hline 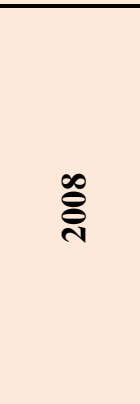 & $\begin{array}{l}\text { Rena rates ISO } \\
9001: 2000 . I t \text { sets out the } \\
\text { criteria for a quality } \\
\text { management system and is } \\
\text { the only standard in the } \\
\text { family that can be certified. }\end{array}$ & $\begin{array}{l}\text { Introduced } \\
\text { clarifications to } \\
\text { the existing } \\
\text { requirements of } \\
\text { ISO 9001:2000 } \\
\text { and some } \\
\text { changes intended } \\
\text { to improve } \\
\text { consistency with } \\
\text { ISO 14001:2004. }\end{array}$ & & & \\
\hline ڤ્̀े & $\begin{array}{l}\text { Supplemented directly to } \\
\text { ISO 9001on how to make a } \\
\text { quality management system } \\
\text { more efficient and effective. }\end{array}$ & & & & $\begin{array}{l}\text { Managing } \\
\text { for the } \\
\text { sustained } \\
\text { success of } \\
\text { an } \\
\text { organization. } \\
\text { A quality } \\
\text { management } \\
\text { approach. }\end{array}$ \\
\hline$\frac{\pi}{4}$ & \multicolumn{5}{|c|}{ To be published in September 2015} \\
\hline
\end{tabular}

Poh Ngoh Kiew, Syuhaida Ismail and Aminah Mohd Yusuf (2016), The Journal of Organizational Management Studies, DOI: $10.5171 / 2016.117211$ 
However, only ISO 9001 is directly audited against for third party assessment purposes. Over a million organizations worldwide are independently certified (ISO, 2010). The ISO conducts a survey worldwide with ISO 9001 certificates had been awarded worldwide at the end of the year 2014 (The ISO, 2014). The average 6.72 percent have increased per year from 2000 to 2014; where its significance shows the gradual increased global adoption of ISO 9001 as illustrated in Table 4.

\section{Table 4: Worldwide Total of ISO 9001- Quality Management System-Requirement Certificates}

\begin{tabular}{|l|r|r|r|}
\hline \multirow{2}{*}{ Year } & \multicolumn{3}{|c|}{ Requirements Certificates } \\
\hline $12 / 1 / 2000$ & No of Company & Accumulative & Yearly Percentage Increased \\
\hline $12 / 1 / 2001$ & 457,834 & 457,834 & $0 \%$ \\
\hline $12 / 1 / 2002$ & 510,349 & 968,183 & $11 \%$ \\
\hline $12 / 1 / 2003$ & 561,767 & $1,529,950$ & $10 \%$ \\
\hline $12 / 1 / 2004$ & 497,919 & $2,027,869$ & $-11 \%$ \\
\hline $12 / 1 / 2005$ & 660,132 & $2,688,001$ & $33 \%$ \\
\hline $12 / 1 / 2006$ & 773,867 & $3,461,868$ & $17 \%$ \\
\hline $12 / 1 / 2007$ & 896,929 & $4,358,797$ & $6 \%$ \\
\hline $12 / 1 / 2008$ & 951,486 & $5,310,283$ & $3 \%$ \\
\hline $12 / 1 / 2009$ & 982,832 & $6,293,115$ & $8 \%$ \\
\hline $12 / 1 / 2010$ & $1,064,785$ & $7,357,900$ & $5 \%$ \\
\hline $12 / 1 / 2011$ & $1,118,510$ & $8,476,410$ & $-1 \%$ \\
\hline $12 / 1 / 2012$ & $1,111,698$ & $9,588,108$ & $0 \%$ \\
\hline $12 / 1 / 2013$ & & $9,588,108$ & $1.54 \%$ \\
\hline $12 / 1 / 2014$ & $1,126,460$ & $9,602,870$ & $1.22 \%$ \\
\hline
\end{tabular}

Source: From ISO (2015)

Hence, the ISO 9000 has caused construction companies to focus only on improving the implementation of ISO9000 certified by accreditation bodies, as they can achieve their performance in accordance with the international standards with guidance from the International Accreditation Forum (IAF). Their performances are generally measured or assessed based on their operation within financial constraints, successfully gaining market position and obtaining profitability. Evidence from Hong Kong shows that this is especially true for Small and Medium
Enterprises (SMEs) in the service and construction sectors (Lee, 1998). Furthermore, Sonny Nwankwo (2000) finds that image is one of the factors that motivate a company to adopt ISO 9000 certification.

According to Tang et al. (2005), large contractors are enjoying benefits from implementing ISO 9000 QMS, whilst the smaller companies reports difficulties and obstacles. In Malaysia, enforcement is done by CIDB towards those large construction companies under Grade 7 to compulsorily be 
certified with ISO certification if they wish to bid for public projects. Despite that, a view from Master Builders Association of Malaysia (MBAM, 1995) agrees that the effective quality management system that meets the ISO 9000 standard can lead to cost and time savings and better quality projects. However, although more construction companies are being certified with ISO certification, they always have wrong perception that would have competitive edge in bidding contract and a low tender price is still the main factor in winning contracts. In addition, countries such as the United Kingdom (UK), Hong Kong and Singapore reveal that the ISO 9000 implementation is very encouraging at the initial stage but over the time, it becomes burdensome to all parties involved if the right approaches are not adopted (Giles, 1997; Kam and Tang, 1997; Abdul and Mat, 2006). For instance, the companies are always trapped in the ISO 9000 registration on the excessive overhead and paperwork; and there will be the risk of poor company image if the certificate process or maintenance failed. Therefore, ISO 9000 is seen lay down what QMS must do but not how QMS should do.

\section{Conclusion}

Construction industry is a very complicated industry. To meet the objectives of the construction management, strategic management techniques are vital. However, specific quality management knowledge areas are required in managing the construction activities throughout the whole project life cycle from pre-contract to postcontract phase. Hence, the integration of the Quality Management System (QMS) into the practices of construction industry is observed by this paper as essential to achieve better management of the construction activities. Among the benefits of integrating the QMS: improving the company's quality image in the construction industry, improving the company's efficiency and management, resolving the problems with poor quality arising construction processes, reducing the failure costs and liability risks, fulfilling the mandate from the Government, satisfying the demands from the private owners/clients and becoming a stepping stone for implementing Total Quality Management (TQM). It is also important to adopt the eight principles of Total Quality Management (TQM) from Dr. Deming's Fourteen Points, which include customer focus, leadership, involvement of people, process approach, system approach to management, continual improvement, factual approach to decision making and mutually beneficial supplier relationship. Proper implementation of QMS is expected to efficiently manage the construction activities throughout the 360 degree of project life cycle.

\section{Acknowledgment}

The authors would like to express their sincere gratitude to the Ministry of Education Malaysia, Universiti Teknologi Malaysia (UTM) and the Research Management Centre (RMC) of UTM for providing the financial support for this paper to be published. This study is financed by the Grant for Research University (GUP) Tier 1 of UTM for research funding under Cost Centre No. Q.K130000.2540.11H09.

\section{References}

1. Abdul, H. and Mat, N. (2006). Quality Management System in Construction. Universiti Teknologi Malaysia, Skudai, 81310 Johor Bahru Johor, Malaysia.

2. Al-Momani, A.H. (2000). Examining Service Quality With Construction Processes. Technovation, 20(11), 643-651.

3. Austin, S., Newtonb, A., Steele, J., and Waskett, P. (2002). Modelling and manging project complexity. International Journal of Project Management,20:191-198.

4. Beattie, Ken R. (1999). Implementing ISO 9000:A Study of Its Benefits Among Australian Organizations. Total Quality Management 10: 95. 
5. David, L.G. and Stanley, D. (2013). Quality Management for Organization ExcellenceIntroduction to Rotal Quality. $7^{\text {th }}$ Edition. Pearson Education Inc.

6. Giles, R. (1997). ISO 9000 Perspective for Construction Industry in the UK. Training for Quality. 5(4),178-181.

7. Jack R. M. and Samuel J.M. (2006). Project Management - A managerial Approach. $6^{\text {th }}$ Edition. John Wiley \& Sons, Inc. 235-282.

8. Jay H. and Barry R. (2014) Principles of Operations Management- Sustainability and Supply Chain Management. $9^{\text {th }}$ Edition. Pearson Education Limited. England. 245246.

9. Kam, C.W. and Tang, S. L. (1997). Development and Implementation of Quality Assurance in Public Construction Works in Singapore and Hong Kong. International Journal of Quality \& Reliability Management. 14(9), 909-928.

10. Kanji, G., and Wong, A. (1998). Quality Culture in the Construction Industry. Quality Management, 9(4-5), 133-140.

11. Karim, K., Marosszeky, M., and Kumaraswamy, M. (2005). Organizational Effectiveness Model for Quality Management Systems in the Australian Construction Industry. Total Quality Management \& Business Excellence, 16(6), 793-806.

12. Lahndt, L. (1999). TQM Tools for the Construction Industry. Engineering Management Journal, 11(2), 23-27.

13. Lee, T.Y. (1998). The Development of ISO 9000 Certification and the Future of Quality Management. International Journal of Quality and Reliability Management. 15(2), 162-77.

14. Love, P. E. D., Mandal, P., and Li, H. (1999). "Determining the causal structure of rework influences in construction." Constr. Manage. Econ.,17(4), 505-517

15. McIntyre,C., and Kirschenman, M. (2000). Survey of TQM in Construction Industry in Upper Midwest. Journal of Management in Engineering, 16(5), 67-70.

16. Nesan, L. J., and Holt, G. D. (1999). Empowerment in Construction: the Way Forward for Performance Improvement. Hertfordshire, England: Research Studies Press LTD.

17. Nwankwo, S. (2000). Quality Assurance in Small Business Organisations: Myths and Realities. International Journal of Quality \& Reliability Management. 17(1), 82-99.

18. Peter, H., Pascale, C. and Todd, L. (2010). Barriers and Benefits of Quality Management in the Construction Industry : an Empirical Study . Total Quality Management and Business Excellence. 21(9).953-969. Routledge Taylor \& Francis Group.

19. Serday, D. (2011). Pareto Analysis of On-Site Productivity Constraints and Improvement Techniques in New Zealand Building Industry. School of Engineering and advanced Technology College of sciences, Massey University at Albany, New Zealand.

20. Tang, S.L., Syed, M.A., Raymond, T.A. and Poon, S.W. (2005). Construction Quality Management. Condor Production Co. Ltd. Hong Kong, China. 2(2.1). 2005.

21. Tenth Malaysia Plan (2011-2015). The Economic Planning Unit, Prime Minister's Department, Putrajaya.

22. Tsim, Y.C., Yeung, V.W.S., Leung, Edgar T.C. (2002). An Adaptation to ISO 9001:2000 for Certified Organisation. Managerial Auditing Journal 17 (5): 245.

23. Yeoh, S.K. and Lee, N.C. (1996). ISO 9002 in the Malaysian Construction Industry-Guide and Implementation. McGraw-Hill Book Co. Malaysia 